\title{
A Longitudinal Analysis of the Effects of Instructional Strategies on Student Performance in Traditional and E-Learning Formats
}

\author{
Retta Sweat-Guy and Craig Wishart \\ Fayetteville State University, Fayetteville, North Carolina, USA
}

\section{rguy@uncfsu.edu cwishart@uncfsu.edu}

\begin{abstract}
As more and more colleges and universities offer courses designed in the e-learning format, quality of instruction and student performance are becoming, progressively more, issues that need to be addressed. This study is an attempt to add to the literat ure on student performance in traditional and e-learning environments as well as exploring student-centered and learner-centered as an instructional strategy. A causal-comparative design was chosen for this study to examine the effects of instructional strategies on student performance in two upper-level core business courses developed in both traditional and e-learning formats. The study spanned 3 years, beginning fall 2004 through spring 2007 and participants included 293 declared business majors who were enrolled in various sections of Organizational Behavior and International Management courses during the study period. Dat a analyses revealed non significant differences in student performance based on delivery method and course. However, quite the reverse was found when examining student performance against instructional strat egies.
\end{abstract}

Keywords: e-learning, student performance, instructor-centered, student-centered, instructional strategy, traditional environment.

\section{Introduction}

As the institution of higher education repositions to move forward in the e-learning paradigm, quality issues that directly impact student performance are of paramount importance (Husson \& Waterman, 2002; Sweat-Guy \& Buzzetto-More; 2007b).

The most recent Sloan Consortium report confirms that enrollment in online courses have increased to an estimated 2.4 million (Simonson, 2006). Arbaugh (2000) asserts that this online trend is due to a variety of factors such as "technological advances in both course soft ware and computing capacity, compet itive pressures from external stakeholders and alternative sources of education, and more flexibility for students". This widespread increase of online courses in col-

Material published as part of this publication, either on-line or in print, is copyrighted by the Informing Science Institute. Permission to make digital or paper copy of part or all of these works for personal or classroomuse is granted without fee provided that the copies are not made or distributed for profit or commercial advantage AND that copies 1) bear this notice in full and 2) give the full citation on the first page. It is permissible to abstract these works so long as credit is given. To copy in all other cases or to republish or to post on a serveror to redistribute to lists requires specific permission and payment of a fee. Contact Publisher@ InformingScience.org to request redistribution permission. leges and universities across the globe has sparked continuous debate among educators and researchers alike. Regardless of whether a course is hybrid or fully online, there is much debate about what makes these courses effective learning experiences for students.

Proponents of online education argue that this mode of instruction provides flexibility and convenience as well as 
increased student learning and satisfaction (Brunner, 2006; Buzzetto-More \& Sweat-Guy, 2006; Kuo, 2005; Yip, 2004). In contrast, critics emphasize high dropout rates, absence of nonverbal cues, insufficient levels of interaction, and decreased student achievement as reasons to censure the online format (Hirschheim, 2005; Kock, Vervile, \& Garza, 2007).

Despite the popularity of online learning, relatively little research has examined the influence of teaching styles and methodology on objective measures of student learning (DeNeui \& Dodge, 2006). Accordingly, this study was designed to examine the effects of instructional strategies, described by Sweat-Guy and Buzzetto-More (2007c) as methods or approaches used to achieve learning objectives, on student performance in two upper-level business courses developed in traditional and e-learning environments. The following research questions were postulated for this study:

- Are there performance differences based on delivery method?

- Are there performance differences based on course?

- Are there performance differences based on instructional strategies?

\section{Literature Review}

Johnson and Aragon (2003) argue that student performance is directly impacted by the quality of instructional design. When developing online courses, Johnson and Aragon recommend a conceptual framework that represents a holistic perspective which includes instructional strategies that look beyond the traditional paradigm of instruction.

Chen (2007) suggests that instructional design strategies should be modified in order to preserve the quality of learning. Accordingly, she used a blended approach combining objectivist and constructivist instructional strategies in her design of an intensive summer online course and found that students had positive learning experiences and were highly satisfied with their learning outcomes. Chang (2007) investigated the effects of a self-monitoring strategy on student performance in a web-based language learning course and found similar results. Students who applied the self-monitoring strategy outperformed students who did not apply the strategy.

In contrast, the study conducted by Sweat-Guy and Buzzetto-More (2007a) examined the impact of instructor-centered versus learner-centered instructional strategy on student leaming in two online courses. The results revealed no significant difference across treatment groups.

A review of literat ure reports on a number of primary research studies that have provided comparable data on student performance between traditional and e-learning environments, citing the latter with more promising results. Connolly, MacArthur, Stansfield, and McLellan (2007) conducted a quasi-experimental study to investigate student performance in 3 masters-level computer courses that were developed and delivered in online and traditional formats. The study spanned 3 years and included 4,684 participants. Study result s show that online students consistently performed better than face-to-face. Identical results were found by Stansfield, McLellan, and Connolly (2004) who examined the results of four modules from the Masters of Science Management of e-Business program with the purpose of comparing the overall performance of students enrolled in the modules online versus those in the face-to-face. Analysis of the results during the period 2000-2002 shows that online students in all four modules, Technologies for Global Commerce, Information Theory and Practice, International Technology Management, and Fundamentals of Database Systems, consistently performed better than the students enrolled in the face-toface modules.

DeNeui and Dodge (2006) examined the relationship between the frequency of usage of Blackboard Learning Management System and student performance in a ten week general psychology 
hybrid class. The sample consisted of 80 students enrolled in two introduct ory psychology courses at a medium-sized university in the Northwest. Results revealed a significant positive partial correlation between overall usage and their exam scores. The findings indicate that students who use Blackboard performed better on exams than those who used Blackboard less frequently.

Opposing results were reported by Sapp and Simon (2005) when comparing the grades students received in online and face-to-face undergraduate writing courses. The findings show a disproportionately high percentage of students who failed the online courses compared to conventional, face-to-face courses.

Mixed results were achieved as Ellis, Goodyear,Prosser, and O'Hara (2006) investigate student learning experiences through discussions in online and face-to-face formats in a semester-long psychology course. The participants were second-year undergraduate students studying social work at a metropolitan Australian University. Open-ended questionnaires, semi-structured interviews, and course grades were used to identify associations among conceptions, approaches, and student performance. The study outcome yield mixed results. There was no significant difference bet ween the face-to-face discussions and performance, whereas, discussions online were associated with higher level of performance.

A study conducted by Kock et al. (2007) supports both the significant- and no-significantdifference perspectives after examining students' perceptions and grades at two points in time. The study involved 70 undergraduate students enrolled in a management information systems course delivered face-to-face and online at a midsized university in the southern United States. At the middle of the semester, students in the online condition obtained lower grades; conversely, by the end of the semester no significant differences were found. Likewise, a similar study conducted by Carbonaro, Dawber, and Arav (2006) compared undergraduate nursing students' achievement using mid-term and final exam grades of full- and part-time students in face-to-face and online sections. The study covered the 3 treatment groups of students enrolled in a microbiology course that ran concurrently for 16 weeks. The results revealed no significant statistical difference of the midterm exam; on the other hand, full time students in the face-to-face environment outperformed students in the online environment.

A number of researchers have compared student performance in traditional versus online courses and have found no significant difference between the two modes of instruction. The following studies add to the literat ure that states student learning, as measured by performance, does not appear to be different based on course delivery method. The study conducted by McFarland and Hamilton (2005) involved senior-level undergraduate MIS students who were enrolled in an EBusiness course during the fall 2003 and fall 2004 semesters. Students self-selected into either the traditional section or the online section. Using Chi-Square analysis, results found no significant difference in the final course grade between the online students and the traditional students. Hoban, Neu, and Castle (2002) conducted a similar study, fort wo academic semesters, which compared the performance of student teacher candidates seeking state certification through the educational administration program at National University in both on-ground and online delivery modes. Dat collection included student surveys, grades, and a comprehensive exit examination. The results revealed that the students academically performed comparably in on-ground and online courses and that established standards were mastered by both groups.

Kovačić and Green (2004) conducted an empirical study to determine the relationship between student learning styles and academic achievement in an Internet-based computer concepts course. Data collection for one academic semester included final grades and responses from the Kolb and Felder-Soloman's Index of Learning Styles questionnaires. The investigators found no relationship between preferred learning styles and academic performance. In the study conducted by Up- 
ton (2006) Speech and Language Therapy undergraduate majors were enrolled in both a traditional and online health psychology/sociology module in which their performances were compared. Results suggested that there was no significant difference between students taught through an online medium compared to those taught through traditional lectures.

As a final point, there is an abundance of literat ure that investigates student performance in traditional and online courses which focuses on a one-shot-cross sectional analysis of effects (Kovačić \& Green, 2004; Ellis et al., 2006; Stansfield et al., 2004; Upton, 2006). Nevertheless, few longitudinal studies of this nature exist that analyze dat a different points in time (Connolly et al., 2007). Recent empirical evidence suggests that students' attitude, perception, and performance can differ over time (Kock et al., 2007; Qureshi \& Vogel, 2000). Hence, the current study investigates the effects of student performance conducted over a 3 -year period.

\section{Background and Methodology}

This study was conducted at Fayetteville State, a historically Black land-grant university founded 1867 in Fayet teville, North Carolina. A constituent institution of the University of North Carolina, Fayetteville State University (FSU) is the second oldest public institution in the state. It currently serves a growing population of approximately 5,600 of which 73\% are African Americans, $18 \%$ Caucasians, $4 \%$ Hispanic, and 5\% other races. Fifty-seven percent are between the ages of 17-24, while $43 \%$ are reported as non-traditional students that are employed, commuting, single parents, adults with families, and/or retired military personnel.

FSU is a teaching, research and doctoral institution that began offering Baccalaureate degrees in business administration in 1971. Over the ensuing years, the School of Business and Economics expanded its program to include degrees in accounting, economics, banking and finance, management information systems, as well as the Masters of Business Administration. In 2006, the School of Business and Economics received accreditation from the Association to Advance Collegiate Schools of Business (AACSB) a distinguished accrediting instit ution for business programs in higher education.

A causal-comparative design was chosen for this study to examine the effects of instructional strat egy on student performance in two upper-level core business courses developed in traditional and e-learning formats. The study spanned 3 years, beginning fall 2004 through spring 2007. Participants included 293 declared business majors who were enrolled in various sections of Organizational Behavior and International Management during the study period. The courses are requisites for all business majors toward graduation with further requirements to maintain at least a GPA of 2.5 in all core courses. The traditional and e-learning course sections ran concurrently and were facilitated by the same instructor who holds a Ph.D. in Organizational Behavior with extensive research and consulting experience internationally. Additionally, the instructor received training and support from the University's Center for Innovation in Teaching and Learning through various workshops, seminars, webcasts and webinars on the subject of online plat forms, specifically the Blackboard Learning Management System, and online course design prior to the development of both courses. The instructor subsequently designed five undergraduate and graduate online business courses for the University, two of which are the focus of this study.

The traditional-based sections of both courses met face-to-face for 2.5 hours per week for a semester long 16 weeks. The weekly sessions were comprised of lectures and discussions based on assigned readings, which were comprised of book chapters and related articles. Academic requirements for both courses (as presented in Table 1) included a variation of chapter quizzes, case analysis, participation, and formative and summative examinations. Class participation was measured by the quantity and quality of oral contributions. 
The Blackboard Learning Management System was used to deliverthe e-learning courses with teaching and learning tools that foster course development, course delivery, and course management. For the courses designed in the e-learning format, the instructor provided lecture notes and PowerPoint slides in which the content of such were identical to the lectures and presentations delivered orally in the traditional-based format. The course readings, aside from the adopted textbook, were made available to the e-learning sections electronically as PDF files. The discussion board was used to facilitate both collaborative learning among students and open dialogue with the instruct or on the assigned readings and chapter content. The threaded discussions represented class participation in the e-learning environment and was measured by the quantity and quality of electronic postings by each student. There were no face-to-face meetings of the elearning sections, all interactions took place online. Additionally, Blackboard was used for the administration of all quizzes, examinations, and submission of written assignments for the traditional and e-learning sections of both courses.

Table 1: Course Requi rements \& Grading Criteria

\begin{tabular}{|c|c|c|c|c|}
\hline & \multicolumn{2}{|c|}{ Organizational Behavior } & \multicolumn{2}{|c|}{ International Management } \\
\hline \multirow{4}{*}{ Year 1} & 16 Chapter Quizzes & $20 \%$ & 14 Chapter Quizzes & $20 \%$ \\
\hline & 2 Case Analysis & $75 \%$ & 14 One Page Papers & $25 \%$ \\
\hline & Participation & $5 \%$ & 2 Case Analysis & $50 \%$ \\
\hline & & & Participation & $5 \%$ \\
\hline \multirow{5}{*}{ Year 2} & 16 Chapter Quizzes & $15 \%$ & 14 Chapter Quizzes & $15 \%$ \\
\hline & 2 Case Analysis & $50 \%$ & 14 One Page Papers & $15 \%$ \\
\hline & 4 Exams & $30 \%$ & 1 Case Analysis & $25 \%$ \\
\hline & Participation & $5 \%$ & Midterm \& Final Exams & $40 \%$ \\
\hline & & & Participation & $5 \%$ \\
\hline \multirow{5}{*}{ Year 3} & 16 Chapter Quizzes & $15 \%$ & 14 Chapter Quizzes & $15 \%$ \\
\hline & 2 Case Analysis & $50 \%$ & 14 One Page Papers & $15 \%$ \\
\hline & 4 Exams & $30 \%$ & 1 Case Analysis & $25 \%$ \\
\hline & Participation & $5 \%$ & Midterm \& Final Exams & $40 \%$ \\
\hline & & & Participation & $5 \%$ \\
\hline
\end{tabular}

Throughout the three-year study period, the instructor employed various strategies and methods in an attempt to improve final grades each year. In the first year, the courses were designed using the student centered approach to teaching and learning, in which the students were responsible for managing the pace and depth of their learning (Sweat-Guy \& Buzzetto-More, 2007c). The chapter quizzes for both courses were made available to the students on Blackboard to take at their own pace during the semester. They were primarily intended to be self-study tools, but also served as a means of assessing student learning. The quizzes were comprised of fifteen multiplechoice and true/false questions randomly selected from a database of 120-150 questions that were timed for completion in fifteen minutes. Additionally, students were allowed unlimited attempts in taking the quizzes and were instructed to use them to both assess their reading comprehension and self-determine their desired level of achievement for the course requirement. To demonstrate the students' working knowledge of the course concepts and promote analyticalthinking and 
writing skills, case analyses were used in lieu of examinations, and as a result were weighted heavily with a minimum requirement of 10 pages each. The International Management courses had an additional requirement of 14 one-page papers that summarized current events in the global marketplace. The students were permitted to revise and resubmit their writing assignments to improve their writing skills and self-determine their desired level of achievement.

In year 2, the courses were redesigned using the instructor-centered approach in which activities (e.g. information dissemination and corrective feedback) were guided by the instruct or to provide more structure and control over the learning process (Sweat-Guy \& Buzzetto-More, 2007c). In as much, deadlines were integrated into the courses. While the chapter quizzes were similarly designed and administered, they were due within two weeks of the assigned readings as noted in the syllabus to ensure that the students kept up with the readings. The writing assignments were reduced to no less than eight pages and similarly permitted unlimited revision and resubmission, continuing only until the due date of each assignment. Late submissions of the written and discussion board assignments were not accepted. Multiple-choice exams were introduced to empirically and more adequately assess student comprehension. The exams were comprised of thirty instructor-selected questions from the test bank and were administered online with a one hour time limit. The instruct or not only changed the teaching strategy for year 2, from studentcentered to instruct or-centered, but also added formative and summative evaluations.

In year 3, the courses were designed again using the instructor-centered approach, imposing greater control over the students' participation and learning process. The chapter quizzes were similarly comprised of fifteen questions, but could be attempted only three times, and were timed for completion within ten minutes and one week of the assigned reading. The writing assignments remained at no less than eight pages, but revisions were subject to one grade reduction. The four exams were changed to comprise sixteen instructor-selected multiple-choice questions and eight short answer questions, selected from a pool of twenty-four chapter review questions made available to the students one week before the scheduled exam. The review questions were designed to demonstrate critical thinking and holistic integration of the course concepts. The students were responsible for providing thorough answers to these 24 review questions prior to the exam date. During the one hour timed online exam, they were required to copy their answers into the Blackboard exam file and respond to the sixteen quiz questions. A summary of the instructional strategies and methods used in each year of the study is presented in Table 2.

Table 2: Study Design by Year

\begin{tabular}{|c|c|c|c|}
\hline Format & Year 1 & Year 2 & Year 3 \\
\hline $\begin{array}{l}\text { Traditional \& } \\
\text { e-Learning }\end{array}$ & $\begin{array}{l}\text { Student-Centered } \\
\text { - } \quad \begin{array}{l}\text { Self study assess- } \\
\text { ment }\end{array} \\
\text { - } \text { Case studies } \\
\text { - Discussions } \\
\text { - Writing_unlimited } \\
\text { revisions \& sub- } \\
\text { missions } \\
\text { - } \begin{array}{l}\text { Quizzes- } \\
\text { unlimited attempts }\end{array}\end{array}$ & $\begin{array}{l}\text { Instructor-Centered } \\
\text { - } \quad \text { Self study assessment } \\
\text { - } \quad \text { Case studies } \\
\text { - } \quad \text { Discussions } \\
\text { - Writing_unlimited } \\
\text { revisions \& submis- } \\
\text { sions } \\
\text { - Summative/ Forma- } \\
\text { tive (timed) }\end{array}$ & $\begin{array}{l}\text { Instructor-Centered } \\
\text { - } \begin{array}{l}\text { Self study assess- } \\
\text { ment }\end{array} \\
\text { - } \text { Case studies } \\
\text { - Discussions } \\
\text { - Writing-limited } \\
\text { revisions w/penalty } \\
\text { - } \begin{array}{l}\text { Summative/ For- } \\
\text { mative (timed) }\end{array}\end{array}$ \\
\hline
\end{tabular}

Final grade achieved was used to measure performance of 293 students enrolled in two core courses of the Business Management concentration in both traditional and e-learning formats. 
The dat a collected for the study were analyzed using Cross Tabulations to determine whether there were significant differences between variables. For data analyses, the Statistical Package for Social Sciences (SPSS) was used with the significance level set at a=0.05.

\section{Findings}

In the first phase of the dat a analysis, descriptive statistics were used to provide quantitative summaries of grades by year (instructional strategy), delivery method, and course.

The findings of year 1, as represented in Table 3, show that less than twenty percent (18.8\%) of the students earned grades below the required level in the traditional format. Additionally, $41.3 \%$ earned year-end grades between 92-100,35\% earned between $91-83$, and 5\% earned bet ween 82 73. In the e-learning format, a significant percentage of students failed below acceptable levels (31.9\%), while $29.8 \%$ earned between $100-92,25.5 \%$ earned bet ween $91-83$, and $12.8 \%$ earned between 82-73. Descriptive statistics indicate a larger percentage of year-end grades that averaged between 100 and $73(81.2 \%)$ in the traditional format compared to $(68.1 \%)$ in the e-learning format.

Table 3: Year 1 Final Grade Report

\begin{tabular}{|l|c|c|c|c|}
\hline \multirow{2}{*}{ Course } & \multicolumn{2}{|c|}{ Traditional } & \multicolumn{2}{c|}{ e-Learning } \\
\cline { 2 - 5 } & Count & $\%$ & Count & $\%$ \\
\hline $100-92(\mathrm{~A})$ & 33 & 41.3 & 14 & 29.8 \\
\hline $91-83(\mathrm{~B})$ & 28 & 35.0 & 12 & 25.5 \\
\hline $82-73(\mathrm{C})$ & 4 & 5.0 & 6 & 12.8 \\
\hline 72 and below (Failing) & 15 & 18.8 & 15 & 31.9 \\
\hline
\end{tabular}

Figure 1 depicts a breakdown of year 1 by courses. The descriptive statistics illustrate that the Organizational Behavior traditional course had a larger percentage of year-end grades between 100 and $73(83.3 \%)$ compared to $(79.2 \%)$ in the e-learning course. Similarly, the International Management traditional course had a significantly larger percentage of year-end averages between 100 and $73(75 \%)$ compared to $(56.5 \%)$ in the e-learning course.

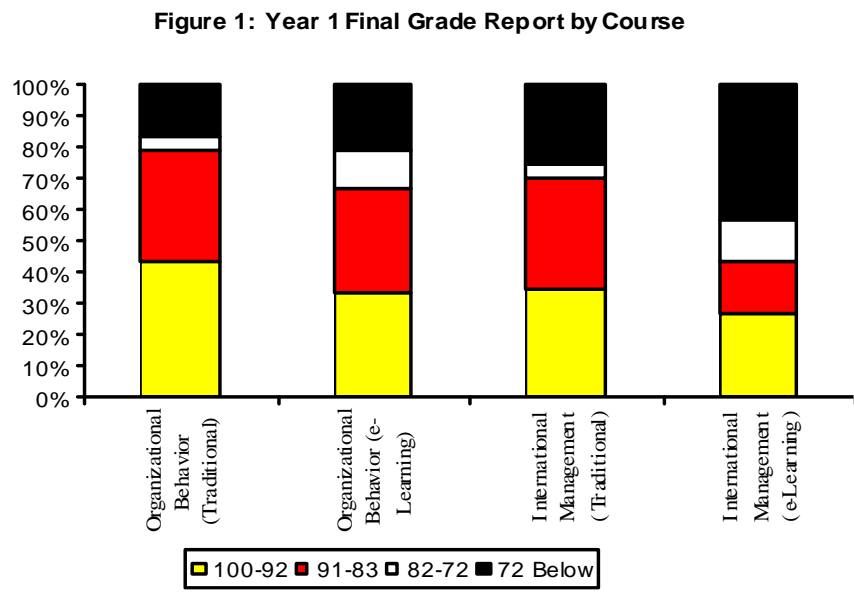

Year 2, as displayed in Table 4, shows $21.3 \%$ earned final averages bet ween 100-92, 19.1\% earned between $91-83,27.7 \%$ earned bet ween $82-73$, and $31.9 \%$ fell below passing in the traditional format. Comparable percentages were reported for the e-learning courses with $18.2 \%$ earning between 100-92, $29.5 \%$ bet ween $91-83,20.5 \%$ between $82-73$, and $31.8 \%$ with averages falling below $73 \%$. Quite the reverse from year 1, the year-end grade averages of year 2 indicate a minute difference (.01) in the percentage of scores between 100 and $73(68.2 \%)$ in the e-learning format compared to $(68.1 \%)$ in the traditional format. 
Table 4: Year 2 Final Grade Report

\begin{tabular}{|l|c|c|c|c|}
\hline \multirow{2}{*}{ Course } & \multicolumn{2}{|c|}{ Traditional } & \multicolumn{2}{c|}{ e-Leaming } \\
\cline { 2 - 5 } & Count & $\%$ & Count & $\%$ \\
\hline $100-92(\mathrm{~A})$ & 10 & 21.3 & 8 & 18.2 \\
\hline $91-83(\mathrm{~B})$ & 9 & 19.1 & 13 & 29.5 \\
\hline $82-73(\mathrm{C})$ & 13 & 27.7 & 9 & 20.5 \\
\hline 72 and below (Failing) & 15 & 31.9 & 14 & 31.8 \\
\hline
\end{tabular}

Mixed results were found in year 2 with a larger percentage of year-end averages between 100 and 73 in the Organizational Behavior course e-learning format $(70 \%) \mathrm{com}$ pared to $(68.4 \%)$ in the traditional format, and in the International Management course traditional format $(67.9 \%)$ compared to $(66.7 \%)$ in the e-learning format (see Figure 2).

In year 3 of the study, a large percentage of students $(40.9 \%)$ earned year-end averages bet ween 100-92 in the traditional format despite $31.8 \%$ earning failing marks. This

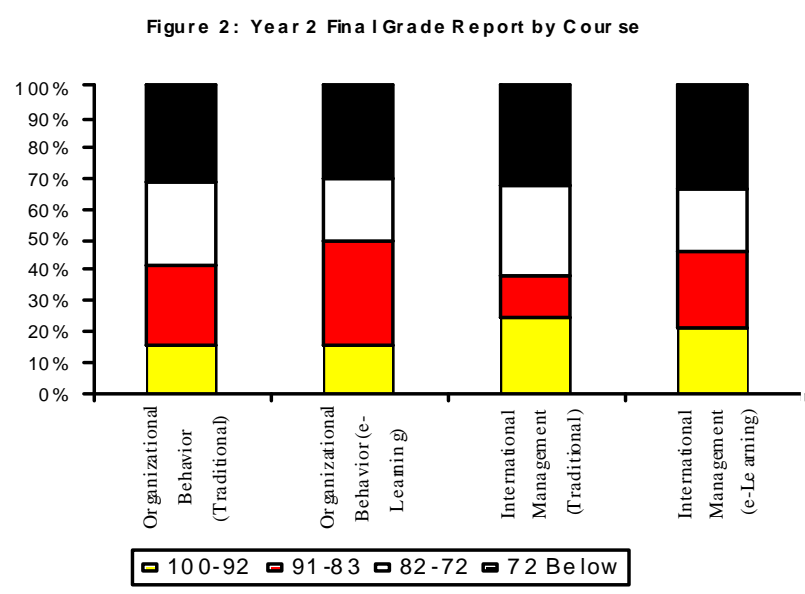
year also reported $11.4 \%$ earning scores between $91-83$ and $15.9 \%$ earning bet ween $82-73$. In the e-learning format, the majority of the students earned grades between 91 and 83 (35.5\%), while only $19.4 \%$ earned between 100-92, $16.1 \%$ earned between $82-73$, and $29 \%$ earned grades below the acceptable average. The frequency distribution, as depicted in Table 5, shows that in year 3 (reminiscent of year 2) a slightly larger percentage of year-end grades averaged between 100 and $73(71 \%)$ in the e-leaming format compared to $(68.2 \%)$ in the traditional format.

Table 5: Year 3 Final Grade Report

\begin{tabular}{|l|c|c|c|c|}
\hline \multirow{2}{*}{ Course } & \multicolumn{2}{|c|}{ Traditional } & \multicolumn{2}{c|}{ e-Leaming } \\
\cline { 2 - 5 } & Count & $\%$ & Count & $\%$ \\
\hline $100-92(\mathrm{~A})$ & 18 & 40.9 & 6 & 19.4 \\
\hline $91-83(\mathrm{~B})$ & 5 & 11.4 & 11 & 35.5 \\
\hline $82-73(\mathrm{C})$ & 7 & 15.9 & 5 & 16.1 \\
\hline 72 and below (Failing) & 14 & 31.8 & 9 & 29.0 \\
\hline
\end{tabular}


Synonymous with year 2, year 3 yield mix results with a larger percentage of year-end averages between 100 and 73 in the Organizational Behavior course e-learning format $(70.6 \%)$ compared to $(61.3 \%)$ in the traditional format, and in the International Management course traditional format $(84.6 \%)$ compared to $(71.4 \%)$ in the e-learning format (see Figure 3).

In the second phase of the data analysis, a series of cross tabulations of category frequencies were computed to determine if correlation exist between final grades and the study variables (delivery method, course, and instructional strategy).

The first cross tabulation examined the relationship bet ween final grades and delivery method. The results are expressed in Table 6. A Chi-Square Test was run to obtain a measure of statistical significance with the significance level set at $a=0.05$. The Chi-Square Test indicates that $p>.05$ (.141) and cannot be regarded as significant (see Table 7). Accordingly, we conclude that there is not sufficient evidence to assert that a relationship exists between final grade and delivery method.

Table 6: Delivery Me thod Cross Tabulation

\begin{tabular}{|l|r|r|}
\hline \multicolumn{1}{|c|}{ Final Grade } & Face-to-Face & \multicolumn{1}{c|}{ Online } \\
\hline $100-92(\mathrm{~A})$ & $20.8 \%$ & $9.6 \%$ \\
\hline $91-83(\mathrm{~B})$ & $14.3 \%$ & $12.3 \%$ \\
\hline $82-73(\mathrm{C})$ & $8.2 \%$ & $6.8 \%$ \\
\hline 72 and below (Failing) & $15.0 \%$ & $13.0 \%$ \\
\hline Total & $58.4 \%$ & $41.6 \%$ \\
\hline
\end{tabular}

Table 7: Delivery Me thod Chi-Square Test

\begin{tabular}{|l|r|r|r|}
\hline & \multicolumn{1}{|c|}{ Value } & df & \multicolumn{1}{c|}{$\begin{array}{c}\text { Asymp. } \\
\text { Sig. }\end{array}$} \\
\hline Pearson Chi-Square & $5.458^{\mathrm{a}}$ & 3 & .141 \\
\hline Likelihood Ratio & 5.565 & 3 & .135 \\
\hline Linear-by-Linear Association & 3.383 & 1 & .066 \\
\hline N of Valid Cases & 293 & & \\
\hline
\end{tabular}

a. 0 cells $(.0 \%)$ have expected count less than 5. The minimum expected count is 18.32 . 
The second cross tabulation correlated final grade by course (see Tables 8 and 9) and found results to be non significant, p>.05 (.221). As such, we conclude that there is not sufficient evidence to assert that a correlation ex its between final grade and course.

Table 8: Course Cross Tabulation

\begin{tabular}{|l|r|r|}
\hline \multicolumn{1}{|c|}{ Final Grade } & $\begin{array}{c}\text { Organizational } \\
\text { Behavior }\end{array}$ & $\begin{array}{c}\text { International } \\
\text { Management }\end{array}$ \\
\hline $100-92(\mathrm{~A})$ & $17.4 \%$ & $13.0 \%$ \\
\hline $91-83(\mathrm{~B})$ & $18.1 \%$ & $8.5 \%$ \\
\hline $82-73(\mathrm{C})$ & $7.8 \%$ & $7.2 \%$ \\
\hline 72 and below (Failing) & $15.0 \%$ & $13.0 \%$ \\
\hline Total & $58.4 \%$ & $41.6 \%$ \\
\hline
\end{tabular}

Table 9: Course Chi-Square Test

\begin{tabular}{|l|r|r|r|}
\hline & \multicolumn{1}{|c|}{ Value } & df & \multicolumn{1}{c|}{$\begin{array}{c}\text { Asymp. } \\
\text { Sig. }\end{array}$} \\
\hline Pearson Chi-Square & $4.409^{\mathrm{a}}$ & 3 & .221 \\
\hline Likelihood Ratio & 4.482 & 3 & .214 \\
\hline Linear-by-Linear Association & .888 & 1 & .346 \\
\hline N of Valid Cases & 293 & & \\
\hline
\end{tabular}

a. 0 cells $(.0 \%)$ have expected count less than 5. The minimum expected count is 18.32 .

The third and final cross tabulation was run in order to determine whether correlation exist between final grade and instructional strategy. The results, as revealed in Tables 10 and 11, were found to be statistically significant $\mathrm{p}<.05(.005)$, thereby the authors support the claim that instructional strategies impacted students final grade.

Table 10: Instructional Strategy Cross Tabulation

\begin{tabular}{|l|r|r|r|}
\hline \multicolumn{1}{|c|}{ Final Grade } & \multicolumn{1}{c|}{ Year 1 } & \multicolumn{1}{c|}{ Year 2 } & \multicolumn{1}{c|}{ Year 3 } \\
\hline $100-92(\mathrm{~A})$ & $16.0 \%$ & $6.1 \%$ & $8.2 \%$ \\
\hline $91-83(\mathrm{~B})$ & $13.7 \%$ & $7.5 \%$ & $5.5 \%$ \\
\hline $82-73(\mathrm{C})$ & $3.4 \%$ & $7.5 \%$ & $4.1 \%$ \\
\hline 72 and below (Failing) & $10.2 \%$ & $9.9 \%$ & $7.8 \%$ \\
\hline Total & $43.3 \%$ & $31.1 \%$ & $25.6 \%$ \\
\hline
\end{tabular}


Table 11: Instructional Strategy Chi-Square Test

\begin{tabular}{|l|r|r|r|}
\hline & \multicolumn{1}{|c|}{ Value } & df & \multicolumn{1}{c|}{$\begin{array}{c}\text { Asymp. } \\
\text { Sig. }\end{array}$} \\
\hline Pearson Chi-Square & $18.387^{\mathrm{a}}$ & 6 & .005 \\
\hline Likelihood Ratio & 18.879 & 6 & .004 \\
\hline Linear-by-Linear Association & 3.787 & 1 & .052 \\
\hline N of Valid Cases & 293 & & \\
\hline
\end{tabular}

a. 0 cells $(.0 \%)$ have expected count less than 5. The minimum expected count is 11.26.

\section{Discussion}

Throughout the first year, the instructor monitored the course gradebooks on Blackboard, which revealed that few students were taking the quizzes or submitting discussion board assignments with any regularity untilthe last month and weeks of the semester. Despite numerous appeals throughout the semester that they keep up with the readings and the corresponding assignments, only a few students remained current and were prepared for class. With busy work and school schedules, the students indicated that they were prioritizing course work for their other more demanding classes that had instructor imposed deadlines and severe penalties for failing to attend class. Since both classes emphasized written assignments that could be revised and resubmitted for evaluation, students benefited from improving their papers. The effort invested in the revisions largely determined their course grade. The students were submitting up to three and four revisions to improve their grade, in view of that, the instructor recognized that time demands of this method of assessment was unsustainable. While many dedicated students achieved A's and B's in the courses, there were also a disproportionate number of students that failed to complete the assignments and subsequently failed the class.

In the following year, the instructor sought to create more structure by imposing deadlines for submission of assignments to help students more adequately control the pace of their learning and to limit the time commitment for instruct or evaluation. The quizzes were due within two weeks of the assigned readings and late submissions of the written and discussion board assignments were not accepted. While some students completed the quizzes according to schedule, many failed to complete the assignments on time. Consequently, the Blackboard quizzes were made available to the students one week prior to the exams to assist in their preparation. Unfort unately, students disclosed that in the time allotted they were using the book to look up the answers.

Recognizing that students with comparatively poor writing skills were disadvantaged in the first year, the instructor introduced multiple-choice exams, and reduced the weight and length of the written assignments. Additionally, because of the perceived burden of written assignments in the International Management course, only one case analysis was required in the second year. In most cases, these results of the multiple-choice exams mirrored the student's performance on the quizzes. During this year, the results of student performance more closely resembled a normal grade curve, yet there remained a large number of students that did not complete the course assignments and failed the courses.

In the third year, the instructor imposed further restrictions upon the course assignments to provide more structure to the learning process. The quizzes were due within one week of the assigned reading to provide a stricter deadline intended to keep the students current with reading 
assignments. Additionally, the time allotted for the quizzes was reduce do ten minutes to prevent the use of their books and more accurately reflect reading comprehension. Unfortunately, after the first exam, the instruct or discovered a discrepancy between the quiz and exam scores in the Organizational Behavior courses, in which students who failed the quizzes achieved high scores on the exam. Investigation revealed that students were taking the online exams collectively and sharing answers. Consequently, eight short answer questions were included in the exams for the remainder of the year. As a result of the change in examination methods, a disproportionate number of students withdrew or failed the Organizational Behavior courses

A recent survey conducted by Sungard (2006) at FSU indicated that students reported their overall experience with online courses as excellent or good. Additionally, more than $80 \%$ of the students indicated that they felt comfortable with (a) their level of preparedness to take an online course, (b) their level of computer skills and knowledge, and (c) their ability to address any problems or issues they faced during the course. While the survey result s provided by Sungard (2006) only offer a baseline assessment of students' perceptions of proficiency and satisfaction with FSU's online program and do not assess the comparative quality of the traditional courses, they do suggest that the students are capable of managing in an e-learning environment.

\section{Contributions and Study Limitations}

This study provides initial research on a population that has previously been overlooked in the literat ure. The findings undoubtedly contribute to the body of research conducted at majority institutions that focus on student performance in less than traditional formats. Moreover, it provides initial research on adapting instructional strategies in order to sustain student performance in e-learning environments.

Interpretations of these findings are limited by the delimitations of the present study; explicitly, grades are used as a measure of the extent to which the student successfully complies with the academic requirements set forth by Fayetteville State University in conjunction with the UNC Board of Regents. Secondly, the study focuses solely on participants attending a minorityserving institution. A third limitation regarding the use of chat or synchronous communication tools were absent in the e-learning format; the primary use of asynchronous tools (e-mail and discussion boards) were utilized to conduct course activities and discussions. Lastly, the e-learning courses were created and delivered using Blackboard; however, caution should be used in generalizing the findings using different e-learning platforms.

\section{Summary and Future Research}

As more and more colleges and universities offer courses designed in the e-learning format, quality of instruction and student performance are becoming, progressively more, issues that need to be addressed. Proponents of the online medium support its convenience and web-based tools for instruction and learning; yet, at the same time, those in opposition demand continuous investigations to ensue quality and high-levels of student performance.

This study sought to determine whether student performance differs based on delivery method, course, and instructional strategies. The findings revealed that the delivery method did not impact student performance. However, the contingency table 6 shows that students in the face-toface sections $(58.4 \%)$ outperformed those in the online sections $(41.6 \%)$. In likeness to the findings of this study, the reviewed literat ure reveals a predominance of non significant differences found between the two modes of delivery (Carbonaro, et al, 2006; Hoban, et al., 2002; Kock et al., 2007; McFarland \& Hamilton, 2005; Upton, 2006).

A non-significant difference was found when examining final grade against course. Further analysis revealed that students in the Organizational Behavior course $(58.4 \%)$ performed better 
than students enrolled in the International Management course (41.6\%) as illustrated in table 8. Instructional strategies, methods, and assessments were reviewed and modified each year based on student performances in prior year. A statistical significant difference was found when comparing final grades against instructional strategies. The cross tabulation table 10 shows that students in year $1(43.3 \%)$ outperformed those in year $2(31.1 \%)$ and year $3(25.6 \%)$. The results of the current study were inconsistent with the study conducted by Sweat-Guy and Buzzetto-More (2007a) who found a non-significant difference when examining student centered and instruct or centered instructional strategies against student performance. The data gathered and findings of this study can be used to inform future planning and the implement ation of e-learning courses.

It is import ant to continue a careful and never-ending study of e-learning (web-based teaching and learning) in order to leverage its strengths while avoiding its limitations. To create quality and effective courses using we b-based technologies, we must challenge its ability to augment what we cannot do in the traditional classroom instead of trying to imit ate its model and/or conceptual framework.

\section{References}

Arbaugh, J. (2000). How classroom environment and student engagement affect learning in internet-based MBA courses. Business Communication Quarterly, 63(4), 9-26.

Brunner, D. (2006). The potential of the hybrid course vis-à-vis online and traditional courses. Teaching Theology and Religion, 9(4), 229-235.

Buzzetto-More, N., \& Sweat-Guy, R. (2006). Incorporating the hybrid learning model into minority education at a historically black university. Journal of Information Technology Education, 5, 153-164. Retrieved from http://jite.org/documents/Vol5/v5p153-164Buzzetto130.pdf

Carbonaro, M., Dawber, T., \& Arav, I (2006). A comparison of students' perform ance under full-time and part-time, and online conditions in an undergraduate nursing microbiology course. Journal of Distance Education, 21(1), 51-61.

Chang, M. (2007). Enhancing web-based language learning through self-monitoring. Journal of Computer Assisted Learning, 23(3), p. 187-196.

Chen, S. (2007). Instructional design strategies for intensive online courses: An objectivist-constructivist blended approach. Journal of Interactive Online Learning, 6(1), 72-86.

Connolly, T., MacArthur, E., Stansfield, M., \& McLellan, E. (2007). A quasi-experimental study of three online learning courses in computing. Computers \& Education, 49(2), 345-359.

DeNeui, D., \& Dodge, T. (2006). Asynchronous learning networks and student outcomes: The utility of online learning components in hybrid courses. Journal of Instructional Psychology, 33(4), 256-259.

Ellis, R., Goodyear, P., Prosser, M., \& O'Hara, A. (2006). How and what university students learn through online and face-to-face discussion: Conceptions, intentions and approaches. Journal of Computer Assisted Learning, 22(4), 244-256.

Hirschheim, R. (2005). The internet-based education bandwagon: Look before you leap. Communications of the ACM, 48(7), 97-101.

Hoban, G., Neu, B., \& Castle, S. (2002). Assessment of student learning in an educational administration online program. Paper presented at the American Education Research Association (AERA) Annual Meeting, New Orleans, Louisiana.

Husson, W., \& Waterman E. (2002). Quality measures in distance learning. Higher Education in Europe, 27(3), 253-260.

Johnson, S., \& Aragon, S. (2003). An instructional strategy framework for online learning environments. New Directions for Adult \& Continuing Education, 100, 31-43. 
Kock, N., Vervile, J., \& Garza, V. (2007). Media naturalness and online learning: Findings supporting both the significant- and no-signi ficant-difference perspectives. Decision Sciences Journal of Innovative Education, 5(2), 333-355.

Kovačić, Z., \& Green, J. (2004). Are all learners created equal? A quantitative analysis of academic performance in a distance tertiary institution. Journal of Issues in Informing Science and Information Technology, 1, 965-976. Retrieved from http://proceedings.informingscience.org/InSITE2004/122kovac.pdf

Kuo, M. (2005). A Comparison of traditional videoconference-based, and web-based learning environments. Online Submission, 1-7. Available at http://eric.ed.gov/ERICDocs/data/ericdocs2sq1/content_storage 01/0000019b/80/1b/df/53.pdf

McFarland, D., \& Hamilton, D. (2005). Factors affecting student perform ance and satis faction: Online versus traditional course delivery. Journal of Computer Information Systems, 46(2), 25-32.

Qureshi, S., \& Vogel, D. (2000). Adaptive processes for achieving socio-technical fit in CSCW groups. In E. Coakes, R. Lloyd-Jones, \& D. Willis (Eds.), The new sociotech: Graffiti on the long wall (pp. 184196). London: Springer-Verlag.

Sapp, D., \& Simon, J. (2005). Comparing grades in online and face-to-face writing courses: Interpersonal account ability and institutional commitment. Computers \& Composition, 22(4), 471-489.

Simonson, M. (2006). Growing by degrees: Latest report from the Sloan Consortium. The Quality Review of Distance Education, 7(2), 7-8.

Stansfield, M., McLellan, E. \& Connolly, T. (2004). Enhancing student performance in online learning and traditional face-to-face class delivery. Journal of Information Technology Education, 3, 173-188. Retrieved from http://jite.org/documents/Vol3/v3p173-188-037.pdf

Sungard Higher Education. (2006). End of the term program evaluation. Fayetteville State University, conducted Fall 2006.

Sweat-Guy, R., \& Buzzetto-More, N. (2007a). Instructor-centered vs. learner-centered: Examining its impact on student learning in an online environment. TCEA Educational Technology Research Sympo sium, $1,137-145$.

Sweat-Guy, R., \& Buzzetto-More, N. (2007b). The attitudes of African American college students towards technology and online learning. TCEA Educational Technology Research Symposium, 1, 146-155.

Sweat-Guy, R., \& Buzzetto-More, N. (2007c). Instructor and student roles in two opposing pedagogies. In N. Buzzetto-More (Ed.), Advanced principles of effective e-learning (pp. 113-131). Santa Rosa, California: In forming Science Press.

Upton, D. (2006). Online learning in speech and language therapy: Student performance and attitudes. Education for Heath: Change in Learning \& Practice, 19(1), 22-31.

Yip, M. (2004). Using Web-CT to teach courses online. British Journal of Educational Technology, 35(4), 497-501.

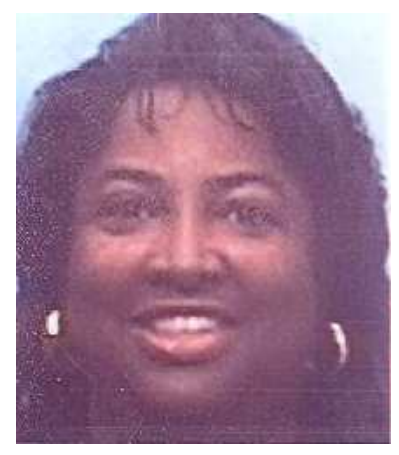

\section{Biographies}

Dr. Retta Sweat-Guy has an Ed.D. in Curriculum and Instruction with emphasis in Instructional Systems Design from the University of Kentucky. She received her masters in Public Administration from Kentucky State University and a Bachelor of Arts degree in Business Education from the University of Kentucky. Currently, she is Assistant Professor in the Department of Marketing and Business Education at Fayetteville State University in Fayetteville, North Carolina. Online teaching and learning serves as the basis for her current research for which she has presented at conferences and published in refereed jour- 
nals and book chapters. She has and continues to conduct workshops and training sessions on the use of web-based course management tools and instructional design for online courses. Her first edited book on mobile learning is scheduled to be released by the end of 2008 .

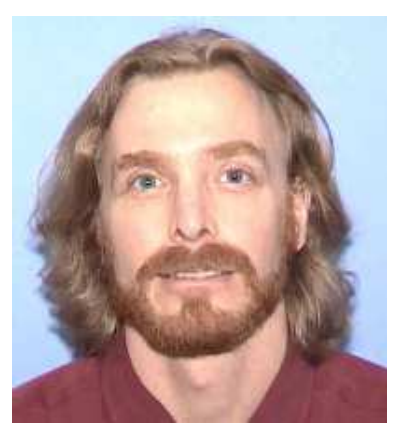

Dr. C raig Wishart has a Ph.D. in Organizational Behavior from Case Western Reserve University. His research and writing has focused upon sustainable community development, education research and reform, as well as change processes in personal and organizational life. Dr. Wishart has fifteen years experience as an organizational consultant in the non-profit and business sectors, including a variety of public, private, educational, community, and international organizations. He has a broad base of experience as a designer and developer of nonprofit business and academic programs, researcher and designer of organizational capacity innovations, designer and facilitator of conferences and team building retreats, and is an author of articles and papers for academics and practitioners. Currently, he is the MBA Director at Fayetteville State University, working to enhance the content, design and delivery of the program. His recent research and scholarship in online learning guides the e-learning changes that signal a significant opportunity for growth in the MBA program. 